\title{
AS FUNÇÕES DA INFORMAÇÃO NO MERCADO DE VALORES MOBILIÁRIOS E SUA DIVULGAÇÃO OBRIGATÓRIA: ANÁLISE DE DECISÕES JUDICIAIS SOBRE A RESPONSABILIDADE CIVIL DA COMPANHIA ABERTA POR VIOLAÇÕES DO DEVER DE INFORMAR
}

\author{
Alexandre Ferreira de Assumpção Alves* \\ Ricardo Villela Mafra Alves da Silva**
}

O artigo tem por objetivo examinar o dever de informar da companhia aberta e as funções da informação no mercado de valores mobiliários a partir de 4 decisões judiciais em que se discutiu a responsabilidade civil da companhia perante investidores por falhas informacionais. Adotou-se o método científico indutivo, modo a extrair conclusões dos casos concretos, a partir de pesquisa documental e bibliográfica. Como contribuição, sustenta-se que as decisões analisadas podem viabilizar a construção de uma jurisprudência sobre o dever de informar da companhia assentada na aplicação das normas societárias e do mercado a partir das funções exercidas pela informação.

Palavras-chave: Companhias abertas; mercado de valores mobiliários; informação; dever de informar; responsabilidade civil.

\section{THE PURPOSES OF INFORMATION IN THE SECURITIES MARKET AND MANDATORY DISCLOSURE: ANALYSIS OF JUDICIAL DECISIONS REGARDING THE CIVIL LIABILITY OF PUBLICLY-TRADED CORPORATIONS FOR VIOLATIONS OF THEIR DUTY TO INFORM}

The article aims to examine the publicly-traded corporation's duty to inform and the purposes of information in the securities market based on 4 judicial decisions in which courts discussed the civil liability of the corporation with respect to investors for informational violations. The article adopted the inductive scientific method, to extract conclusion from concrete cases, using documental and bibliographical research. As contribution, it argues that the decisions analyzed may enable the construction of a jurisprudence regarding the corporation's duty to inform based on the application of corporate and securities laws taking into account the purposes of information in the market.

Key-words: Publicly-traded corporations; securities market; information; duty to inform; civil liability.

\footnotetext{
* Professor de Direito da Universidade Federal do Rio de Janeiro (FND - UFRJ), professor do programa de pósgraduação stricto sensu da UFRJ na linha de pesquisa Empresa e Atividades Econômicas. É membro do Conselho Editorial da Revista Semestral de Direito Empresarial (RSDE). Pesquisador líder do grupo de pesquisa Empresa e Atividades Econômicas, do DGP do CNPq. Expositor convidado na Escola da Magistratura do Estado do Rio de Janeiro (EMERJ) desde 1994. Possui graduação em Direito pela UFRJ, mestrado em Direito pela UERJ, e doutorado em Direito pela UERJ. E-mail: asaa@uol.com.br

** Advogado. Mestre e Doutorando pela Faculdade de Direito da Universidade do Estado do Rio de Janeiro (UERJ). Professor substituto de Direito Comercial da Faculdade de Direito da UERJ. E-mail: ricardovmafra@gmail.com
} 


\section{INTRODUÇÃO}

O mercado de valores mobiliários possui grande relevância na economia, pois propicia a destinação da poupança popular a empresas conduzidas por companhias abertas (BRASIL, 1976, p. 1). O legislador estabeleceu como um dos objetivos da regulação deste mercado a promoção do seu funcionamento eficiente ${ }^{1}$ e, para isso, impôs diversas obrigações de divulgação de informação aos emissores de valores mobiliários. Logo, o cumprimento do dever de informar pela companhia é relevante, por ser este um dos principais pilares da regulação.

$\mathrm{O}$ artigo tem por objetivo examinar o dever de informar da companhia e as funções da informação no mercado de valores mobiliários a partir de 4 decisões judiciais em que se discutiu a responsabilidade civil da companhia perante investidores por falhas informacionais. De forma específica, o trabalho buscará determinar se estas decisões tratam de modo adequado o dever de informar da companhia aberta e se podem servir de base para a construção de uma futura jurisprudência sobre o tema.

A fim de dar concretude aos objetivos, a seção 2 apresentará a base normativa dos deveres de informação da companhia, previstos na Lei $n^{\circ}$ 6.385/1976 e nas normas emitidas pela Comissão de Valores Mobiliários (“CVM"). A seção 3 será dedicada à análise das funções que a informação exerce no mercado de valores mobiliários. Por fim, a seção 4 será voltada ao exame das decisões em que o dever de informar da companhia foi objeto de discussão e que podem servir de orientação para a resolução de futuros casos.

$\mathrm{O}$ artigo adota o método científico indutivo, de modo a extrair conclusões dos casos concretos analisados sobre a responsabilidade da companhia aberta por violações do dever de informar, a partir de prévia exposição da doutrina e da legislação, a fim de subsidiar as conclusões obtidas. A pesquisa realizada foi de cunho documental e bibliográfico.

\section{O DEVER DE INFORMAR NA COMPANHIA}

\footnotetext{
${ }^{1}$ Artigo $4^{\circ}$, II e III, da Lei no ${ }^{\circ} 6.385 / 1976$.
} 
O dever legal de prestar informações ao mercado e o regime de divulgação obrigatória caminham de mãos dadas, pois "de nada adiantaria a existência do princípio da transparência se os participantes do mercado não fossem juridicamente obrigados a fornecer ao público as informações a eles e a seus títulos pertinentes" (MILLER, 2004, p. 115).

A divulgação obrigatória de informações nas companhias possui três eixos centrais, que contemplam acionistas, investidores de mercado ou ambos, e impõe o dever de informar a administradores, ao emissor de valores mobiliários e ao acionista controlador (SZTAJN, 2013, p. 232). Enquanto algumas informações visam "a atender interesses tanto de membros da sociedade quanto do mercado", outras têm por objetivo "atender apenas a demandas internas focadas, usualmente, na criação e preservação da confiança entre sócios e administradores da sociedade" (Idem, p. 217).

O dever de informar dos administradores, embora seja importante instrumento de tutela dos interesses dos acionistas, é insuficiente para garantir os direitos de investidores de mercado, em função do seu escopo estrito (GUARRIDES, 1982, p. 49). Faz-se necessário ultrapassar os limites subjetivos próprios do direito do acionista à informação para um dever mais amplo de divulgação ao público investidor (Idem, 1982, p. 50).

O direito brasileiro, a exemplo de outros ordenamentos, como o norte-americano, , adotou o regime de divulgação obrigatória de informações pelas companhias como a principal forma de tutelar a confiança dos investidores nos mecanismos de troca (PITTA, 2013, p. 193194) e protegê-los de abusos no uso de informações privilegiadas por pessoas que tenham acesso a informações da companhia em função do cargo que ocupam (corporate insiders) (BRASIL, 1976, p. 5). Em função do regime de divulgação obrigatória, a lógica puramente privatista do acesso à informação pelo acionista é substituída por uma "disciplina publicística da informação", reforçando o perfil institucional da companhia (MILLER, 2004, p. 97).

$\mathrm{O}$ mercado de valores mobiliários pode ser dividido, quanto à sua regulação, em 2 modalidades: (i) primário, no qual são realizadas as ofertas públicas, quando valores mobiliários são ofertados ao público investidor (PEREIRA FILHO, 2017, p. 341), seja por meio de uma emissão de novos valores mobiliários (oferta primária), seja por meio de uma venda de valores mobiliários já emitidos (oferta secundária) (SALDANHA; MALUF, 2017, p. 804); e (ii) secundário, onde os valores mobiliários são negociados por seus titulares em ambiente de negociação regulado, como a bolsa de valores, e tem a função primordial de conferir liquidez aos investimentos (PITTA; PEREIRA FILHO, 2017, p. 36). 
No caso de ofertas públicas realizadas no mercado primário, o art. 19, caput, da Lei n $6.385 / 1976$ dispõe que nenhuma emissão pode ser distribuída sem o prévio registro na CVM. O $§ 5^{\circ}$, II, do mesmo artigo dá ao órgão atribuição de emitir normas sobre (i) as informações que devem instruir o pedido de registro da oferta pública, inclusive sobre a própria companhia emissora e os seus empreendimentos, (ii) as características da emissão e o uso dos recursos que serão captados, (iii) o vendedor dos valores mobiliários (no caso de uma oferta secundária, em que as figuras do emissor e do ofertante podem ser distintas) e (iv) os participantes da distribuição, sua remuneração e relacionamento com a emissora ou ofertante. Ademais, o artigo $19, \S 6^{\circ}$, da Lei $\mathrm{n}^{\circ} 6.385 / 1976$ determina que a CVM pode condicionar a realização da oferta ao fornecimento de informações que julgar pertinentes para a proteção dos investidores.

No contexto de uma oferta pública de valores mobiliários, o principal objetivo da regulação é garantir que os investidores tenham acesso a informações adequadas sobre a oferta e os ativos ofertados (JAKOBI; RIBEIRO, 2014, p. 120), de modo a reduzir a assimetria de informações entre o ofertante e os destinatários da oferta (BUSCHINELLI, 2015, p. 394).

A Instrução CVM n 400/2003, que estabelece o regime das ofertas primárias e secundárias no mercado primário, endereçou a necessidade de fornecimento de informação em diversos dispositivos. O artigo 38 determina que o prospecto da oferta deve conter “informação completa, precisa, verdadeira, atual, clara, objetiva e necessária, em linguagem acessível, de modo que os investidores possam formar criteriosamente a sua decisão de investimento".

A respeito da responsabilidade pelo fornecimento de informações, o artigo 56 é categórico: “[o] ofertante é o responsável pela veracidade, consistência, qualidade e suficiência das informações prestadas por ocasião do registro e fornecidas ao mercado durante

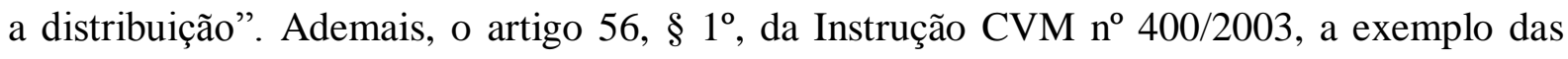
normas que a antecederam, impõe ao intermediário a obrigação de tomar todas as cautelas e agir com elevados padrões de diligência para garantir a veracidade e suficiência das informações prestadas pelo ofertante ao mercado.

Em uma oferta pública, as informações são geralmente concentradas no prospecto, que é o documento mais importante da oferta (EIZIRIK, 2011, p. 28). O prospecto caracteriza um documento de oferta pública sui generis, na medida em que os ofertantes (fundadores) 
propõem "um contrato plurilateral associativo a ser celebrado pelos aceitantes (subscritores) entre si, tendo por objeto a constituição da companhia" (LOBO, 2017, p. 514).

Quanto às operações no mercado secundário, o artigo 21, § 6 $6^{\circ}$ II, da Lei nº 6.385/1976 delega à CVM poderes para expedir normas sobre as informações e documentos que as companhias devem apresentar para obter o registro de companhia aberta. O artigo 21-A, por sua vez, permite que a autarquia emita normas referentes à natureza das informações mínimas e à periodicidade de sua apresentação por pessoas que tenham acesso a informação relevante. $\mathrm{O}$ artigo 22 estabelece, em seu $\S 2^{\circ}$, que compete à CVM expedir normas acerca das informações, quem devem divulgar e a periodicidade da divulgação.

As informações divulgadas no mercado secundário são distintas daquelas divulgadas em ofertas públicas realizadas no mercado primário. No mercado primário, as informações dizem respeito à oferta e aos valores mobiliários ofertados, enquanto no mercado secundário, as informações (divulgadas periodicamente) dizem respeito ao emissor e o seu desempenho econômico (SZTAJN, 2013, p. 224; JAKOBI; RIBEIRO, 2014, p. 120).

Atualmente, a divulgação de informações no mercado secundário é regida pela Instrução $n^{\circ}$ 480/2009, que dispõe, de forma geral, sobre o registro de companhia aberta e as obrigações do emissor de valores mobiliários negociados publicamente. O artigo 13 impõe ao emissor de valores mobiliários a obrigação de divulgar informações periódicas e eventuais, nos prazos e na forma prescrita na referida norma. Como o próprio nome sugere, as informações periódicas são divulgadas pelo emissor de tempos em tempos, em datas préestabelecidas, enquanto as eventuais são fornecidas ao mercado mediante a ocorrência de eventos específicos.

As informações periódicas fornecidas pelas companhias referem-se aos documentos listados nos 18 incisos do artigo 21 da referida Instrução CVM, enquanto as eventuais divulgadas pelas companhias são aquelas listadas nos 43 incisos do artigo 30. A divulgação destes dados visa a dar publicidade sobre determinados eventos relevantes nos negócios sociais, como a realização de assembleias extraordinárias, especiais ou de debenturistas, celebração de acordos de acionistas, elaboração de determinadas políticas ou a ocorrência de fato ou ato relevante, dentre várias outras hipóteses.

A Instrução CVM n ${ }^{\circ}$ 480/2009 foi precisa a respeito da responsabilidade da companhia por violações do seu dever de informar, dispondo, em seu artigo 46, que “[a] responsabilidade atribuída ao diretor de relações com investidores não afasta eventual 
responsabilidade do emissor, do controlador e de outros administradores do emissor pela violação das normas legais e regulamentares que regem o mercado de valores mobiliários".

\section{AS FUNÇÕES DA INFORMAÇÃO NO MERCADO DE VALORES MOBILIÁRIOS}

A importância da informação e a sua adequada divulgação no funcionamento do mercado de valores mobiliários advém das funções que ela exerce. A informação exerce função econômica, pois gera impacto na decisão de investimento; exerce também função regulatória, pois auxilia a supervisão do mercado pelo seu regulador; por fim, exerce função jurídica, ao fomentar a boa-fé objetiva das partes durante a execução de compra e venda de valores mobiliários e, assim, garantir a confiança dos investidores nos mecanismos de troca. O exame destas funções é relevante para que se reconheça o caráter precipuamente instrumental da informação (e, consequentemente, da sua divulgação) no mercado de valores mobiliários.

Do ponto de vista econômico, informação é uma observação que muda a crença e é relevante para a precificação de ativos cujo valor depende de eventos ainda desconhecidos (ARROW, 2013, p. 8). No mercado de valores mobiliários, a informação traz benefícios tanto para as companhias, quanto para investidores, resultantes da redução de riscos, melhora nas decisões operacionais e obtenção de lucros na negociação de títulos (FAMA; LAFFER, 1971, p. 290). Em um mercado livre e competitivo, o próprio preço é uma informação importante. Conforme demonstrado por Friedrich Hayek (1945, p. 525-526), o sistema de preços cumpre tarefa informacional ao indicar tendências de oferta e demanda de produtos e serviços.

Um aspecto relevante para este trabalho refere-se ao impacto que a informação (ou a sua falta) gera no desempenho de mercados em sua função de subsidiar a decisão de alocação de recursos. A literatura é vasta neste campo, especialmente com relação à assimetria informacional. O impacto que os diferentes níveis de informação produzem no desempenho do mercado é tamanho, que economistas como Joseph Stiglitz (2017, p. 5), afirmam não ser possível presumir que mercados são eficientes, sendo mais correto presumir a sua ineficiência.

A assimetria de informações é fonte de alguns problemas econômicos que podem afetar o funcionamento dos mercados. Em clássico estudo, George A. Akerlof (1970, p. 488) se debruçou sobre os impactos da incerteza no contexto da teoria do mercado, demonstrando 
que a falta de informação gera custos econômicos associados à desonestidade. Com base em seu conhecido exemplo hipotético do mercado de carros usados sem informação adequada sobre a sua qualidade, o autor explica que, quando não há informações seguras sobre a qualidade de produtos negociados no mercado, os compradores tenderão a descontar o preço de todos eles, sejam de boa ou má qualidade, o que acabará por afastar bons ofertantes (AKERLOF, 1970, p. 489-490). O custo de desonestidade gerado pela falta de informações pode, em última instância, inviabilizar a própria existência do mercado (Idem, p. 495). Em casos menos extremos, a falta de informação pode prejudicar o funcionamento do mercado ao dificultar que agentes econômicos distribuam riscos e custos entre si de forma adequada (ARROW, 2013, p. 7). Este efeito negativo da assimetria informacional sobre o funcionamento do mercado e a formação de preços foi denominado seleção adversa, pois acaba beneficiando produtos e serviços ruins, em detrimento dos que possuem boa qualidade (YAZBEK, 2009, p. 41).

Além de causar seleção adversa, a insuficiência de informações também gera custos de transação aos agentes de mercado, muitas vezes associados a questões de custos de agência, como conflito de interesses, risco moral e oportunismo (SZTAJN, 2013, p. 221). Em seus estudos sobre os custos de transação, Ronald H. Coase (1960, p. 15) concluiu que a realização transações comerciais impõe custos relacionados à falta de informação sobre quem está disposto a negociar e em quais termos. Os principais custos incorridos pelos agentes econômicos são os custos de coordenação (custos despendidos para estruturar o negócio, buscar parceiros comerciais e clientes) e custos de motivação (custos decorrentes da assimetria de informações, quando as partes não possuem todos os dados relevantes sobre quem está disposto a negociar e sobre os termos da negociação) (FORGIONI, 2008, p. 315).

Além de exercer função econômica, a informação também exerce função regulatória. A regulação pressupõe uma atuação judicante do Estado sobre o domínio econômico voltada à consecução de objetivos de política econômica e social (FREIRE, 2008, p. 24). Embora a intervenção estatal na economia não seja a regra, ela é permitida na forma de exploração direta da atividade econômica pelo Estado, conforme autorizado pelo artigo 173, caput, da CRFB/1988, mas desde que necessária aos imperativos de segurança nacional ou a relevante interesse coletivo, conforme disposto em lei. Também o Estado atua por meio de exercício de poder normativo e regulador, de acordo com o artigo 174, caput, da CRFB/1988. 
A disponibilidade de informação no mercado de valores mobiliários é necessária para corrigir distorções relacionadas, principalmente, à assimetria informacional. Assim, é razoável afirmar que há fundamentos de ordem econômica e política que justificam certo grau de intervenção estatal no mercado de valores mobiliários. Por este motivo, o Brasil adotou o princípio da divulgação obrigatória de informações como pedra fundamental da regulação do mercado de valores mobiliários (TANJI, 2013, p. 106-108).

Bernard S. Black, em seu extenso estudo sobre as bases necessárias para a construção de um mercado de valores mobiliários sólido, cita diversas características que a regulação e o ambiente institucional, de forma geral, devem apresentar, destacando, dentre elas, a existência de uma cultura de divulgação de informações entre participantes do mercado (BLACK, 2001, p. 790-799).

A transparência é benéfica para o mercado e necessária para a regulação por alguns motivos. Em primeiro lugar, ela reduz os custos de monitoramento dos próprios investidores (isto é, os custos de agência) e os custos de supervisão do regulador. Neste contexto, a transparência sobre os negócios do emissor auxilia na dissuasão e/ou na identificação de eventual comportamento inadequado de administradores e controladores (PITTA, 2013, p. 98). Em segundo lugar, a obrigatoriedade de divulgação de informações impede que administradores e controladores manipulem as informações, selecionando apenas aquelas que possam dar a aparência de bom desempenho, em detrimento de outras que poderiam demonstrar uma visão mais ampla dos negócios da sociedade (Idem, p. 99-100).

A divulgação de informações também possui a relevante função de reduzir a quantidade delas às quais só os administradores e controladores têm acesso, mitigando o risco de negociações de valores mobiliários com seu uso ou seu aproveitamento privado (Idem, p. 100).

Deve-se ressaltar, ainda, que os órgãos reguladores e autorreguladores também utilizam as informações divulgadas por emissores de valores mobiliários no desempenho de suas atribuições. Ainda que estes órgãos possam ter acesso a informações que não sejam de divulgação obrigatória, as informações disponibilizadas publicamente podem ser usadas nas suas atividades de físcalização (Idem, p. 106). Desse modo, o regime de divulgação obrigatória de informações assume uma função adicional de prevenir ilícitos cometidos por agentes de mercado (LEÃES, 1982, p. 101). Os registros de ofertas e outras operações envolvendo valores mobiliários também auxiliam na prevenção de ilícitos, pois permitem que 
o regulador identifique irregularidades antes mesmo delas produzirem efeitos (LEÃES, 1982, p. 103).

Assim, a relevância da informação no mercado de valores mobiliários está associada não só às suas funções econômicas, ao subsidiar a decisão do investidor, como também às suas funções regulatórias, na medida em que fortalece a atuação fiscalizatória e repressora do ente regulador. Não obstante, a informação também cumpre um papel mais amplo no direito, atrelada à sua estreita relação com a boa-fé objetiva das partes de um negócio jurídico, que deve ser analisado em razão da sua relevância para o presente estudo.

Por fim, a informação também exerce funções jurídicas. A informação é um tema presente em várias áreas do direito, tanto no direito público, como no caso do acesso a informações governamentais ${ }^{2}$ e o direito constitucional de acesso à informação de forma mais ampla $^{3}$, como no direito privado, passando por questões como o direito à privacidade ${ }^{4}$, e a proteção de dados pessoais ${ }^{5}$ e o direito do consumidor à informação sobre os produtos e serviços ofertados ${ }^{6}$. A pesquisa, no entanto, não se dedica à informação de forma geral, mas sim em um contexto negocial mais estrito (isto é, de negociação de valores mobiliários).

No contexto negocial, a informação possui estreita relação com a boa-fé objetiva que as partes de um negócio jurídico devem observar, a qual demanda efetiva colaboração na consecução do adimplemento (FABIAN, 2002, p. 61). Em um negócio jurídico, a informação pode dizer respeito à própria obrigação principal, a um dever anexo ao dever principal, um dever lateral de proteção, um dever legal ou mesmo um ônus ou encargo material (MARTINS-COSTA, 2015, p. 224).

No direito societário e do mercado de valores mobiliários, a informação possui caráter instrumental, considerando-se suas funções (Idem, p. 529-530), e apresenta caráter transindividual, pois seu fornecimento é necessário para o funcionamento do mercado como um todo, e "configura dever que transcende a relação jurídica inter-individual” (Idem, p. 532).

\footnotetext{
${ }^{2}$ Cf. Lei $n^{\circ} 12.527 / 2011$.

${ }^{3}$ Cf. art. $5^{\circ}$, XIV, da CRFB/1988.

${ }^{4}$ Cf. art. $5^{\circ}, \mathrm{X}$, da CRFB/1988.

${ }^{5}$ Cf. Lei ${ }^{\circ} 13.709 / 2018$.

${ }^{6}$ A informação é mencionada em vários dispositivos da Lei no 8.078/1990, sendo elencada como direito básico do consumidor (artigo $6^{\circ}$, III), como um dos fatores de proteção da saúde e segurança do consumidor (cf., por exemplo, artigos $8^{\circ}$ e $9^{\circ}$ ) e como fundamento para responsabilização do ofertante, no caso de fornecimento de informações inadequadas (artigo 12, caput). No direito do consumidor, o dever de informar também pode ser associado a uma obrigação mais ampla de transparência pelo fornecedor.
} 
No contexto do mercado de valores mobiliários, a informação não influencia apenas o consentimento esclarecido dos que planejam investir, mas também a confiança, que é essencial ao desenvolvimento e funcionamento do mercado. A regulação da CVM é base referencial para determinar quais informações devem ser fornecidas pelos emissores, mas, nas situações em que não haja clareza sobre o dever informacional nas normas regulatórias, o princípio da boa-fé objetiva pode servir para fundamentar diretamente o dever de informar (Idem, p. 533). A obrigação das companhias de divulgar informações provém da lei e das normas da CVM, mas também encontra lastro no dever de boa-fé, pois tem como importante desdobramento a manutenção da confiança dos investidores nos mecanismos de troca do mercado.

\section{ANÁLISE DE DECISÕES JUDICIAIS SOBRE A VIOLAÇÃO DO DEVER DE INFORMAR DA COMPANHIA}

A mais ampla e completa pesquisa de jurisprudência brasileira sobre a responsabilidade civil da companhia por violações informacionais que se tem ciência foi realizada por Lucas Carneiro Gorgulho Mendes Barros, em dissertação sobre o tema datada de 2021, defendida no Programa de Pós-Graduação da USP. A partir da análise de 69 processos em que investidores buscaram ressarcimento por danos alegadamente sofridos em razão de falhas de divulgação da companhia, o referido autor constatou que a maioria delas foi julgada de forma desfavorável a eles. A conclusão do trabalho foi de que a jurisprudência é incipiente, tratando o tema "com excessiva superficialidade, sem que suas múltiplas facetas e complexidades tenham sido aprofundadas e avaliadas de forma satisfatória" (BARROS, 2021, p. 274).

No entanto, uma análise mais detida de algumas decisões relevantes revela um cenário distinto, com discussões profundas sobre o dever de informar da companhia. Neste sentido, propõe-se nesta seção a análise de 4 decisões relevantes, duas do Superior Tribunal de Justiça (“STJ") e uma do Tribunal de Justiça do Estado de São Paulo (“TJSP”), em casos nos quais se buscou apurar a responsabilidade civil da companhia por violações do seu dever de informar.

O primeiro acórdão relevante em que se discutiu a responsabilidade civil de companhia aberta pelas informações divulgadas a investidores foi proferido no âmbito do 
Recurso Especial n ${ }^{\circ} 1.162 .117 / \mathrm{SP}^{7}$. O caso referiu-se a recurso interposto por investidores em face de acordão proferido pelo TJSP, em demanda que versava sobre um pedido de obrigação de fazer da companhia com relação ao exercício de direitos previstos em bônus de subscrição ${ }^{8}$.

Tais valores mobiliários haviam sido adquiridos pelas recorrentes em 1996 e lhes garantia o direito de subscrever ações entre $1^{\circ}$ e 30 de abril de 2003, pelo preço de $\mathrm{R} \$ 1.000,00$ por lote de 1.000 ações, sendo tal valor corrigido monetariamente e acrescido de juros. Não obstante, caso a companhia realizasse aumento de capital por subscrição privada ou pública com um preço de emissão inferior ao previsto no bônus de subscrição, o valor mobiliário previa uma cláusula de ajuste, que garantia ao seu detentor o direito de subscrever as novas ações pelo mesmo preço de emissão aplicado em tal aumento ${ }^{9}$

Em 1997, a companhia emitiu ações a beneficiários de um Plano de Opção de Compra de Ações, instituído nos termos do art. 168, § 3º da Lei no 6.404/1976. Embora o preço de emissão das ações tenha sido inferior ao previsto no bônus de subscrição, a operação foi desconsiderada para fins da cláusula de ajuste do bônus. Desse modo, os recorrentes ajuizaram ação para obrigar a companhia a emitir as ações vinculadas ao bônus de subscrição pelo mesmo preço das ações emitidas no âmbito do Plano de Opção de Compra de Ações. A ré apresentou reconvenção para obrigar os recorrentes a subscrever as ações pelo preço de emissão previsto no bônus de subscrição, sem acionamento da cláusula de ajuste.

Os dois pedidos foram julgados improcedentes pelo juízo de primeira instância, o que motivou a interposição de apelação pelas partes, tendo ambos os recursos sido improvidos. Por um lado, o pedido do autor seria improcedente, pois o Plano de Opção de Compra de Ações possuiria natureza diversa do bônus de subscrição e sua existência seria conhecida pelos detentores do valor mobiliário. Por outro lado, a reconvenção da ré também seria improcedente, já que o exercício do bônus de subscrição teria como pressuposto a

\footnotetext{
${ }^{7}$ BRASIL. Superior Tribunal de Justiça. Quarta Turma. Recurso Especial no ${ }^{\circ} 1.162 .117 /$ SP. Relator Ministro João Otávio de Noronha, julgado em 04/09/2012, publicado em 20/11/2014.

${ }^{8}$ A mesma controvérsia, com os mesmos fatos, mas envolvendo autores diferentes, foi objeto do Recurso Especial $\mathrm{n}^{\circ}$ 1.325.151/SP (BRASIL. Superior Tribunal de Justiça. Quarta Turma. Recurso Especial $\mathrm{n}^{\circ}$ 1.325.151/SP. Relator Ministro Marco Buzzi, julgado em 17/09/2015, publicado em 27/10/2015).

${ }^{9}$ A redação da cláusula era a seguinte: "Caso sejam efetuados aumentos de capital por subscrição privada ou pública até o término do prazo para o exercício do direito à subscrição, aumentos esses nos quais o preço de subscrição venha a ser inferior ao valor ajustado para o exercício de subscrição com base nos bônus calculados, no período de subscrição dessas ações será ajustado para igualar o preço de subscrição e todas as correções e ajustes subsequentes partirão desse novo patamar" (Cf. página 3 do inteiro teor do acórdão proferido no Recurso Especial $\mathrm{n}^{\circ}$ 1.162.117/SP (BRASIL. Superior Tribunal de Justiça. Quarta Turma. Recurso Especial $\mathrm{n}^{\circ}$ 1.162.117/SP. Relator Ministro João Otávio de Noronha, julgado em 04/09/2012, publicado em 20/11/2014).
} 
possibilidade de os seus titulares poderem se beneficiar do mesmo preço de emissão nos termos do Plano de Opção de Compra de Ações, sendo que a companhia não poderia obrigar os titulares dos bônus a exercerem seus direitos de subscrição por um preço de emissão que não concordavam.

A questão controvertida, portanto, dizia respeito ao teor da cláusula ajuste do preço de emissão das ações referenciadas nos bônus de subscrição, especialmente em relação à sua eventual omissão quanto à desconsideração de aumentos de capital realizados nos termos de Plano de Opção de Compra de Ações. Além disso, os recorrentes alegaram ter havido violação de boa-fé objetiva e descumprimento do dever de informar pela companhia, em função de suposta omissão das condições nos bônus de subscrição.

Ao analisar a lide e as decisões proferidas pelas instâncias inferiores, o relator do caso, ministro João Otávio de Noronha, verificou que a alegada imprecisão na redação da cláusula de ajuste do bônus de subscrição seria decorrente da dúvida sobre a extensão do significado da expressão "aumento de capital por subscrição privada ou pública", especificamente se ela abrangeria a emissão de ações por meio do Plano de Opção de Compra de Ações. Afirmou, assim, que resolução do caso dependeria da interpretação da cláusula de ajuste e, por consequência, da distinção legal entre bônus de subscrição, opção de compra de ações e aumento de capital mediante subscrição pública ou particular de ações.

Quanto aos dois primeiros conceitos, o ministro relator entendeu, em síntese, que o bônus de subscrição e a opção de compra seriam institutos distintos, dadas as diferentes características com relação aos seus beneficiários, à sua onerosidade e aos critérios de determinação do preço de emissão das ações. O relator sustentou, ainda, que o aumento de capital por subscrição de ações não seria equivalente ao aumento decorrente do exercício de direitos previstos em bônus de subscrição ou opção de compra, pois, na primeira operação, o objeto seria a colocação e lançamento das próprias ações, enquanto, nas duas outras, a emissão das ações seria consequência do exercício de direito previsto no bônus ou opção.

De fato, o artigo 166 da Lei $n^{\circ}$ 6.404/1976 é claro ao traçar as hipóteses de aumento de capital: (i) por exercício de direitos decorrentes de bônus de subscrição ou plano de opção de compra de ações (inciso III); e (ii) por deliberação da assembleia-geral (inciso II, no caso de aumento deliberado no limite do capital autorizado, ou inciso IV, no caso de aumento de capital com reforma do estatuto). 
Conforme explica Nelson Eizirik (2011, p. 470), o aumento de capital por exercício de direitos previstos em bônus de subscrição ou plano de opção de compra de ações caracterizase como obrigatório, pois não cabe a avaliação de sua conveniência e oportunidade pelos administradores. Ao contrário das hipóteses do artigo 166, II e IV, da Lei nº 6.404/1976, em que o aumento de capital é gerado por uma decisão da assembleia geral ou do conselho de administração (no caso de aumento no limite do capital autorizado), a hipótese do inciso III resultaria em aumento de capital obrigatório a partir do exercício de direitos de subscrição.

Com base na distinção feita sobre as diferentes hipóteses de aumento de capital e seus impactos na interpretação da cláusula de ajuste do bônus de subscrição, o relator argumentou não ter havido violação de boa-fé objetiva ou do dever de informar pela companhia, visto que inexistente a imprecisão alegada.

O ministro Luis Felipe Salomão teve entendimento distinto e proferiu voto divergente, alegando que haveria a legítima expectativa pelos investidores de que a emissão de ações aos beneficiários do Plano acionaria a cláusula de ajuste do bônus de subscrição. Para chegar a esta conclusão, o magistrado afirmou que não haveria distinção entre a subscrição pública ou particular decorrente de aumento de capital ou de exercício de direitos previstos em bônus de subscrição ou opção de compra ${ }^{10}$.

Não obstante a opinião do magistrado, afirma-se que o exercício dos direitos associados a bônus de subscrição ou plano de opção de compra resultam em aumento de capital de hipótese diversa daquela deliberada pela assembleia geral ou conselho de administração.

No entanto, embora sejam hipóteses distintas de aumento de capital, todas elas envolvem subscrição pública ou particular de ações (exceto no caso de aumento de capital mediante capitalização de reservas e lucros por companhias com ações sem valor nominal, que pode ser realizada sem emissão de novas ações, nos termos do artigo $169, \S 1^{\circ}$, da Lei n $^{\circ}$ 6.404/1976). Além disso, ainda que o artigo 166 faça distinção entre diferentes hipóteses de aumento, a redação do bônus de subscrição não fez qualquer distinção quanto a este tema.

\footnotetext{
10 "Portanto, de tudo o quanto até aqui foi exposto, conclui-se, com absoluta certeza, que o exercício dos direitos decorrentes de 'planos de opções' e dos 'bônus de subscrição', como se pode ver pela abalizada doutrina dominante, acarreta aumentos de capital por subscrição privada de ações, sendo, assim, desinfluente a essa consequência a finalidade dos referidos institutos jurídicos, ou a sua disposição na lei societária" (Cf. página 78 do inteiro teor do acórdão proferido no Recurso Especial nº 1.162.117/SP. Vide BRASIL. Superior Tribunal de Justiça. Quarta Turma. Recurso Especial n $1.162 .117 /$ SP. Relator Ministro João Otávio de Noronha, julgado em 04/09/2012, publicado em 20/11/2014).
} 
Dado que a redação do bônus de subscrição condicionava a aplicação da cláusula de ajuste à subscrição pública ou particular a preço inferior ao previsto no bônus, sem fazer distinção quanto ao ato originador da subscrição, caberia razão aos titulares que teriam a justa expectativa de subscrever ações da companhia ao mesmo preço garantido aos beneficiários do Plano de Opção de Compra de Ações.

Por todos estes fundamentos, o ministro Luis Felipe Salomão decidiu que, se a companhia entendia que a emissão das ações nos termos do seu Plano de Opção de Compra de Ações não acionaria a cláusula de ajuste do bônus de subscrição, informação que deveria ter sido claramente divulgada aos investidores.

Entende-se, em linha com o argumento defendido pelo ministro, que a solução da lide deveria ter se desenvolvido a partir da precisão e clareza da redação do bônus. Se o investidor fosse capaz, a partir da informação recebida, de entender que o preço de emissão das ações do bônus de subscrição não sofreria ajuste em decorrência de subscrição de ações por exercício de opção de compra, não haveria fundamento para pleitearem direito ao ajuste do preço. No entanto, ao que parece, a redação não foi clara, pois não fazia qualquer distinção quanto às hipóteses de aumento de capital por subscrição pública ou particular que poderiam acionar a cláusula de ajuste, muito embora o artigo 166 da Lei n 6.404/1976 permita tal distinção. Logo, entende-se que o bônus de subscrição não continha informação precisa e, portanto, a decisão mais correta teria sido conceder indenização aos investidores pelos danos sofridos (caso comprovados).

A decisão é relevante, pois o STJ se debruçou de forma aprofundada sobre a precisão da informação fornecida pela companhia e a capacidade do investidor de compreendê-la, reconhecendo, ainda que implicitamente, a importância da informação precisa e verdadeira no processo de tomada de decisão do investidor.

Outro caso em que se discutiu a responsabilidade civil da companhia aberta por violação do dever de informar refere-se à Apelação n ${ }^{\circ}$ 9247433-87.2005.8.26.0000 ${ }^{11}$, no qual a $5^{\text {a }}$ Câmara de Direito Privado do TJSP se debruçou sobre o pedido de ressarcimento ajuizado por diversos investidores em face do Banco ABN Amro Real S.A.

\footnotetext{
${ }^{11}$ SÃO PAULO. Tribunal de Justiça do Estado de São Paulo. Quinta Câmara de Direito Privado. Apelação no 9247433-87.2005.8.26.0000. Relatora Desembargadora Christine Santini, julgado em 23/11/2011, publicado em $05 / 12 / 2011$
} 
Em síntese, os autores alegaram que o banco não divulgou, de forma clara, a existência de um contrato epistolar celebrado em 7 de julho de 1998 pelo qual seu antigo controlador havia se comprometido a alienar o controle do Banco Real S.A. ao ABN Amro Bank N.V. Os autores teriam vendido as suas ações ao novo controlador no mercado secundário, por meio de ofertas públicas realizadas em 10 de novembro e 28 de dezembro de 1998, por um preço inferior ao que teriam aceitado caso tivessem conhecimento da venda do controle. A transferência do controle do Banco Real S.A. ao ABN Amro Bank N.V. foi implementada no final do ano de 1999, após aprovação do Banco Central do Brasil.

Os fatos discutidos no litígio ocorreram nos anos de 1998 e 1999, portanto, no período entre a revogação do artigo 254 da Lei n ${ }^{\circ}$ 6.404/1976 (que garantia o tratamento igualitário de acionistas minoritários na alienação de controle) pela Lei n 9.457/1997 e a inserção do artigo 254-A à lei societária pela Lei $\mathrm{n}^{\circ}$ 10.303/2001. O referido artigo 254-A passou a condicionar a alienação de controle à realização de oferta pública de aquisição das ações com direito a voto dos acionistas minoritários por ao menos $80 \%$ do preço pago por ação com direito a voto do bloco de controle. Desse modo, não havia, à época, impedimento para que o ABN Amro Bank N.V. adquirisse o controle do Banco Real S.A. e, em paralelo, adquirisse também, por preços livremente negociados, ações detidas por acionistas minoritários na bolsa de valores.

O juízo de primeiro grau julgou improcedente o pedido de ressarcimento dos autores, determinando que não teria havido falha informacional, pois os investidores já teriam tido conhecimento da alienação do controle por meio da imprensa e que os danos patrimoniais alegados seriam hipotéticos. A decisão foi revertida em segunda instância, quando o TJSP decidiu, por maioria, pela procedência do pedido. Posteriormente, no entanto, a decisão de segunda instância foi revertida pelo STJ no Recurso Especial n ${ }^{\circ} 1.540 .428 / \mathrm{SP}^{12}$.

Em decisão tomada por maioria, nos termos do voto proferido pelo ministro Ricardo Villas Bôas Cueva, o STJ afastou a alegação de que o Banco Real S.A. teria cometido violação do seu dever de informar e decidiu que o dano alegado pelos investidores seria hipotético. O fundamento principal do voto é que o pedido de ressarcimento formulado pelos investidores teria lastro em suposta negociação com informação privilegiada ${ }^{13}$, embora, à

\footnotetext{
${ }^{12}$ BRASIL. Superior Tribunal de Justiça. Terceira Turma. Recurso Especial $\mathrm{n}^{\circ} 1.540 .428 / \mathrm{SP}$. Relator Ministro Ricardo Villas Bôas Cueva, julgado em 06/02/2018, publicado em 16/03/2018.

13 "A pretensão inaugural se funda, portanto, no dever imposto aos administradores de revelar ao público fatos relevantes capazes de influir no mercado investidor (duty of disclosure) e no uso indevido de informações privilegiadas (insider trading), referindo-se os autores, por ambos os fundamentos apresentados, à cessão/alienação do controle acionário do Grupo Real" (cf. página 53 do inteiro teor do acórdão proferido no
} 
época das negociações, os investidores supostamente já tivessem conhecimento da transferência de controle do Banco Real S.A. por meio da imprensa e da tramitação do pedido de alteração de controle acionário perante o Banco Central do Brasil ${ }^{14}$. Além de ter decidido pela ausência de violação de dever de informar, o magistrado observou que não teria havido efetiva demonstração de existência de dano patrimonial efetivo pelos autores.

A respeito do dano, o referido ministro sugeriu que a sua demonstração poderia ser feita por meio da comparação entre o preço recebido pelos investidores e a cotação dos valores mobiliários a partir do momento em que a informação completa foi divulgada ${ }^{15}$ :

O ministro Marco Aurélio Belizze proferiu voto vencido, em que consignou que a controvérsia diria respeito, na verdade, não sobre a existência de negociação de valores mobiliários com informações privilegiadas, mas sim de eventual "inobservância do dever de divulgar Fato Relevante ao mercado investidor referente à alienação do controle da companhia, notadamente por ocasião das ofertas públicas de compra de ações preferenciais" $"$.

O voto do ministro Marco Aurélio Belizze esclareceu fatos importantes para o correto exame do caso, que não tinham sido detalhados nas decisões das instâncias inferiores. Segundo o referido voto, a carta-contrato enviada pelo ABN Amro Bank N.V. ao antigo

Recurso Especial $\mathrm{n}^{\circ}$ 1.540.428/SP. Vide BRASIL. Superior Tribunal de Justiça. Terceira Turma. Recurso Especial n ${ }^{\circ}$ 1.540.428/SP. Relator Ministro Ricardo Villas Bôas Cueva, julgado em 06/02/2018, publicado em $16 / 03 / 2018)$.

14 "A contrario sensu, se os investidores têm ciência da informação por outros meios oficiais diversos da publicação de fato relevante, não se pode afirmar que tenham eles negociado seus títulos sem o conhecimento de fato capaz de influir na cotação das ações e na decisão de vendê-las ou comprá-las. Por conseguinte, em se tratando da alienação do controle de companhia aberta que depende de autorização do governo para funcionar, sujeita, portanto, à prévia autorização dos órgãos competentes, nos termos do art. 255 da Lei no 6.404/1976, não se pode alegar o desconhecimento do fato a partir do momento em que essa autorização se torna pública. No caso em apreço, o pedido dirigido ao Banco Central do Brasil visando à outorga de autorização para a transferência das ações ordinárias remanescentes, como bem destacou o Relator, foi formulado em 6/10/1998, tendo a referida autarquia deliberado pela sua aprovação no dia 7/10/1998" (cf. páginas 57-58 do inteiro teor do acórdão proferido no Recurso Especial ${ }^{\circ}{ }^{\circ} 1.540 .428 / S P$. Vide BRASIL. Superior Tribunal de Justiça. Terceira Turma. Recurso Especial n ${ }^{\circ}$ 1.540.428/SP. Relator Ministro Ricardo Villas Bôas Cueva, julgado em 06/02/2018, publicado em 16/03/2018).

15 "Se o que se busca ressarcir são os danos causados pela venda antecipada de ações, antes da divulgação da venda do controle acionário da companhia ao público investidor, caberia aos autores comprovar a existência de efetivo prejuízo na venda de seus títulos, tendo como parâmetro a comparação entre o preço recebido e a cotação desses papéis a partir do momento em que a informação omitida veio a público". (Página 67 do inteiro teor do acórdão proferido no Recurso Especial n ${ }^{\circ}$ 1.540.428/SP. BRASIL. Superior Tribunal de Justiça. Terceira Turma. Recurso Especial $n^{\circ}$ 1.540.428/SP. Relator Ministro Ricardo Villas Bôas Cueva, julgado em 06/02/2018, publicado em 16/03/2018).

${ }^{16}$ Cf. página 13 do inteiro teor do acórdão proferido no Recurso Especial n ${ }^{\circ} 1.540 .428 /$ SP (BRASIL. Superior Tribunal de Justiça. Terceira Turma. Recurso Especial no 1.540.428/SP. Relator Ministro Ricardo Villas Bôas Cueva, julgado em 06/02/2018, publicado em 16/03/2018). 
controlador do Banco Real S.A. em 29 de junho de 1998, e aceita por este em 7 de julho de 1998, versava sobre a transferência de controle da companhia. No entanto, em 3 de julho de 1998, as partes submeteram ao Banco Central do Brasil o pedido de transferência de uma parcela minoritária do capital social do Banco Real S.A., que foi implementada nos meses seguintes. Foi neste contexto que a companhia divulgou ao mercado que a operação se referia, apenas, a uma "parceria estratégica". Apenas em 6 de outubro de 1998, quando a transferência da parcela minoritária do capital havia sido concluída, o ABN Amro Bank N.V. solicitou autorização do Banco Central do Brasil para assumir o controle do Banco Real S.A., pedido este que foi deferido no dia seguinte, em 7 de outubro de 1998.

A transferência do controle teria sido concluída em 5 de novembro de 1998, mesma data em que o Banco Real S.A. teria noticiado ao mercado sobre a conclusão da operação, divulgada por meio de fato relevante, publicado em 23 de julho de 1998, referente à suposta "parceria estratégica" com o ABN Amro Bank N.V. As ofertas públicas de aquisição das ações detidas por investidores minoritários ocorreram dias depois, em 10 de novembro de 1998 e 28 de dezembro de 1998.

Pela sequência dos fatos e pelo conteúdo das informações que foram apresentadas aos investidores, constata-se que houve clara violação do dever de informar pelo Banco Real S.A. em duas ocasiões. O fato relevante divulgado em 23 de julho de 1998 continha informação inverídica, já que o contrato para transferência de controle da companhia foi classificado como um compromisso de uma "parceria estratégica". Em segundo lugar, em 5 de novembro de 1998, quando a transferência do controle foi efetivamente concluída, novamente a companhia reafirmou a informação divulgada em 23 de julho de 1998, deixando de esclarecer, como deveria ter feito, que o negócio buscava implementar, na verdade, a transferência de seu controle. Tudo isso foi feito às vésperas das ofertas públicas de aquisição direcionadas aos investidores minoritários do Banco Real S.A., que tomaram a decisão de venda de suas ações com base nas informações falsas divulgadas pela companhia. Com base nestes fatos, o ministro Marco Aurélio Belizze decidiu, acertadamente, que houve tentativa deliberada do Banco Real S.A. de levar os seus investidores a erro ${ }^{17}$.

\footnotetext{
17 "Aliás, o deliberado propósito de omitir do mercado o fato relevante consistente na transferência do controle do Grupo Real, mesmo após as negociações das ações dos acionistas minoritários, por meio da oferta pública de compra, evidencia clara tentativa de escamotear a ilicitude do proceder adotado. Somente em 20/11/1999, quando há muito a transferência do controle acionário já se encontrava efetivada e, concluídas as negociações de compra de ações dos acionistas não controladores por meio de ofertas públicas, o Banco Real S.A. dignou-se a, finalmente, divulgar fato relevante, consistente na autorização do Banco Central ao ABN Amro Bank de
} 
Quanto à questão dos danos, o julgador concordou com a decisão do TJSP no sentido de que a apuração deles poderia ocorrer em fase de liquidação de sentença e poderia ter como base o preço pago pelas ações do bloco de controle ${ }^{18}$.

A decisão tomada pelo STJ deve ser criticada quanto a proclamação da inexistência de violação do dever de informar pelo Banco Real S.A. Embora o ministro Marco Aurélio Belizze tenha demonstrado cabalmente que houve divulgação dolosa de informações falsas pela companhia, o tribunal acatou a decisão do ministro relator, em função de os investidores terem supostamente tido conhecimento da transferência de controle da companhia por meio da imprensa. Ainda que os investidores pudessem ter tido acesso à informação correta por outras fontes, isso não excluiria o fato de que o Banco Real S.A. violou o seu dever de informar ao ter divulgado ao mercado, em duas ocasiões distintas, informações inverídicas e dolosamente.

Quanto à inexistência de demonstração de dano efetivo, no entanto, entende-se que o voto vencedor foi adequado, pois, de fato, os investidores parecem ter se limitado a alegar a possibilidade da existência de um dano, deixando de cumprir o seu ônus de demonstrar a existência de um dano patrimonial efetivamente sofrido.

Por fim, cumpre analisar o Recurso Especial $\mathrm{n}^{\mathrm{o}} 1.069 .676 / \mathrm{RS}^{19}$, relacionado, na origem, a um pedido de ressarcimento ajuizado pelo Instituto de Resseguros do Brasil ("IRB") contra companhia aberta e sua controladora à época JC Penney Brasil Comercial Ltda. A demanda estava assentada na alegação de que a controladora teria realizado oferta pública entre 23 de dezembro de 1998 e 30 de dezembro 1998 para adquirir ações preferenciais de sua controlada ao preço de $\mathrm{R} \$ 25,00$ por lote de 1.000 ações, oferta esta que foi aceita pelo IRB. No entanto, em 19 de janeiro de 1999, apenas 19 dias depois do encerramento da oferta, a controladora realizou leilão na bolsa de valores para adquirir ações

participar em até $100 \%$ do capital do Banco Real, da Companhia Real de Crédito Imobiliário e da Companhia Real de Valores - DTVM (e-STJ, fls. 380). Ressai inequívoco, portanto, que a realização das ofertas públicas de compra das ações dos acionistas minoritários deu-se, deliberadamente, sem a imprescindível e anterior divulgação ao público em geral acerca da transferência do controle do Grupo Real ao ABN, em claro prejuízo aos acionistas minoritários e ao mercado como um todo" (Cf. página 31 do inteiro teor do acórdão proferido no Recurso Especial $n^{\circ}$ 1.540.428/SP. BRASIL. Superior Tribunal de Justiça. Terceira Turma. Recurso Especial $n^{\circ}$ 1.540.428/SP. Relator Ministro Ricardo Villas Bôas Cueva, julgado em 06/02/2018, publicado em 16/03/2018).

${ }^{18}$ Cf. página 41 do inteiro teor do acórdão proferido no Recurso Especial $n^{\circ} 1.540 .428 / S P$. Vide BRASIL. Superior Tribunal de Justiça. Terceira Turma. Recurso Especial $\mathrm{n}^{\circ}$ 1.540.428/SP. Relator Ministro Ricardo Villas Bôas Cueva, julgado em 06/02/2018, publicado em 16/03/2018).

${ }^{19}$ BRASIL. Superior Tribunal de Justiça. Terceira Turma. Recurso Especial no 1.069.676/RS. Relator Ministro Sidnei Beneti, julgado em 06/08/2009, publicado em 18/11/2009. 
preferenciais da mesma classe por $\mathrm{R} \$ 37,61$ por lote de 1.000 ações, um valor substancialmente superior ao da oferta.

Segundo alegou o IRB, a controladora deixou de informar que teria intenção de pagar um preço superior ao que constava na oferta, o que motivou a demanda ajuizada contra a companhia e sua controladora.

A controvérsia submetida ao STJ dizia respeito especificamente à possibilidade de compensação de honorários sucumbenciais, já que a demanda foi julgada procedente com relação à controladora, mas improcedente perante a controlada. Segundo o acórdão da Sexta Câmara Cível do Tribunal de Justiça do Estado do Rio Grande do Sul, a companhia não teria legitimidade para figurar no polo passivo da demanda, na medida em que não havia praticado qualquer ato que pudesse gerar os prejuízos alegados pelo IRB. A controladora, por outro lado, foi condenada a ressarcir os prejuízos causados ao investidor em função da omissão de informação quanto às alegadas negociações paralelas que conduzia enquanto realizava oferta pública de aquisição de ações. Segundo o IRB, o valor dos honorários de sucumbência devidos aos seus advogados pela controladora poderia ser compensado com os valores que o próprio IRB devia aos advogados da companhia controlada.

Em voto-vista, em que os pontos controvertidos do caso foram analisados em maiores detalhes, a ministra Nancy Andrighi notou que a acionista controladora havia informado ao mercado, quando lançou a sua oferta pública de aquisição, que estaria disposta a adquirir até $70 \%$ (setenta por cento) das ações preferenciais da companhia, sem que houvesse qualquer menção à intenção de adquirir lotes adicionais de ações que eventualmente permanecessem em circulação, o que caracterizaria violação do dever de informar e de boa-fé pela controladora $^{20}$.

Quanto aos danos, a ministra Nancy Andrighi sustentou que estes deveriam ser equivalentes à diferença do preço por ação pago ao IRB no âmbito da oferta pública de aquisição e aquele praticado no leilão realizado em 19 de janeiro de 1999, de modo que todos os acionistas detentores de ações preferenciais fossem tratados de forma equitativa.

Acredita-se que a decisão do STJ foi acertada ao confirmar a decisão proferida pelo Tribunal de Justiça do Estado do Rio Grande do Sul a respeito da: (i) omissão informacional pela acionista controladora; (ii) ilegitimidade passiva da companhia aberta controlada; e (iii)

\footnotetext{
${ }^{20}$ Cf. páginas 25-27 do inteiro teor do acórdão proferido no Recurso Especial no ${ }^{\circ}$.069.676/RS. Vide BRASIL. Superior Tribunal de Justiça. Terceira Turma. Recurso Especial n ${ }^{\circ}$ 1.069.676/RS. Relator Ministro Sidnei Beneti, julgado em 06/08/2009, publicado em 18/11/2009).
} 
quantificação dos danos. O fato de a controladora ter manifestado o desejo de adquirir até $70 \%$ das ações preferenciais da companhia, sem revelar que teria a intenção de adquirir as que remanescessem após a oferta por um preço superior, pode ter levado investidores a erro. Com relação à ilegitimidade passiva da companhia, não se discutiu a imputabilidade de atos de divulgação de informação imprecisa a ela, mas sim a ausência de violação de dever legal (e por consequência, ato ilícito) e de nexo causal que justificasse a responsabilização civil da companhia.

Percebe-se, pelo exame das decisões feito nesta seção, que as decisões do TJSP e STJ abordaram temas complexos com relação à divulgação do mercado de valores mobiliários. Ainda que não se concorde de forma integral com o mérito da decisão, os tribunais aprofundaram a questão do dever de informar da companhia e seus impactos sobre a tomada de decisão dos investidores.

\section{CONCLUSÃO}

$\mathrm{O}$ artigo investigou o dever de informar da companhia e as funções da informação no mercado de valores mobiliários, além de abordar tais temas a partir do estudo de 4 decisões judiciais em que o tema foi tratado com profundidade.

Adicionalmente aos deveres de informação dos administradores e do acionista controlador, a companhia possui deveres próprios, na qualidade de emissora de valores mobiliários, previstos na Lei n ${ }^{\circ} 6.385 / 1976$ e nas normas emitidas pela CVM, especialmente a Instrução CVM no 400/2003 e Instrução CVM n 480/2009. Demonstrou-se, ainda, que a informação cumpre 3 funções no mercado: (i) a econômica, referente ao seu impacto no processo de tomada de decisão do investidor; (ii) a regulatória, pois ela também é utilizada por órgãos reguladores na fiscalização do mercado; e (iii) a jurídica, decorrente do dever de boa-fé e da necessidade de se fomentar a confiança nos mecanismos de troca do mercado.

As decisões analisadas demonstraram que o TJSP e o STJ levaram em consideração, além das regras societárias e do mercado, as funções da informação, analisando temas como a questão da boa-fé no contexto de emissão de valores mobiliários (Recurso Especial $\mathrm{n}^{\mathrm{o}}$ 1.162.117/SP), o impacto da divulgação de fato relevante na tomada de decisão do investidor (Apelação n ${ }^{\circ}$ 9247433-87.2005.8.26.0000 e Recurso Especial n ${ }^{\circ}$ 1.540.428/SP) e as consequências para o mercado e os investidores geradas pela omissão de informações em uma 
oferta pública de aquisição de ações (Recurso Especial no 1.069.676/RS). Estas decisões, portanto, podem servir de base para a construção da jurisprudência sobre a violação do dever de informar da companhia aberta, que será assentada na aplicação das normas societárias e do mercado a partir das funções exercidas pela informação.

\section{REFERÊNCIAS}

AKERLOF, George A. The Market for "Lemons": Quality Uncertainty and the Market Mechanism. The Quarterly Journal of Economics, Nova York, v. 84, p. 488-500, 1970.

ARROW, Kenneth Joseph. Economic theory and the financial crisis. Procedia - Social and Behavioral Sciences, Amsterdã, v. 77, p. 5-9, 2013.

BARROS, Lucas Carneiro Gorgulho Mendes. A responsabilidade civil das companhias abertas perante investidores: danos individuais decorrentes de falhas na divulgação de informações. Dissertação (Mestrado em Direito) - Faculdade de Direito. Universidade de São Paulo. 2021.

BLACK, Bernard S. The Legal and Institutional Preconditions for Strong Securities Markets. UCLA Law Review, Los Angeles, v. 48, p. 781-855, 2001.

BRASIL. Exposição de Motivos da Lei no 6.385/1976. Disponível em: http://conteudo.cvm. gov.br/legislacao/leis-decretos/lei6385.html. Acesso em 16/09/2020.

BRASIL. Superior Tribunal de Justiça. Quarta Turma. Recurso Especial nº 1.162.117/SP. Relator Ministro João Otávio de Noronha, julgado em 04/09/2012, publicado em 20/11/2014. BRASIL. Superior Tribunal de Justiça. Quarta Turma. Recurso Especial $n^{\circ}$ 1.325.151/SP. Relator Ministro Marco Buzzi, julgado em 17/09/2015, publicado em 27/10/2015.

BRASIL. Superior Tribunal de Justiça. Terceira Turma. Recurso Especial $n^{\circ}$ 1.540.428/SP. Relator Ministro Ricardo Villas Bôas Cueva, julgado em 06/02/2018, publicado em $16 / 03 / 2018$.

BRASIL. Superior Tribunal de Justiça. Terceira Turma. Recurso Especial $n^{\circ}$ 1.069.676/RS. Relator Ministro Sidnei Beneti, julgado em 06/08/2009, publicado em 18/11/2009.

BUSCHINELLI, Gabriel Saad Kik. Artigos 19 e 20. In: CORDONIZ, Gabriela; PATELLA, Laura (Org.). Comentários à Lei do Mercado de Capitais - Lei no 6.385/1976. São Paulo: Quartier Latin, 2015. 
CARNEIRO, Fernanda Pereira; BEZERRA, Fernanda. Regime informacional. In: COMISSÃO DE VALORES MOBILIÁRIOS. Direito do mercado de valores mobiliários. Rio de Janeiro: Comissão de Valores Mobiliários, 2017.

COASE, Ronald H. The problem of social cost. The Journal of Law and Economics, Chicago, v. 3, pp. 1-44, 1960.

EIZIRIK, Nelson. A Lei das S/A Comentada - artigos 121 a 188. São Paulo: Quartier Latin, 2011. v. 2.

EIZIRIK, Nelson. A Oferta Pública de Distribuição de Valores Mobiliários. In: WALD, Arnoldo et al. (coord.). Sociedades anônimas e mercado de capitais - Homenagem ao Professor Osmar Brina Corrêa-Lima. São Paulo: Quartier Latin, 2011.

EIZIRIK, Nelson; GAAL, Ariádna B.; PARENTE, Flávia; HENRIQUES, Marcos de Freitas.

Mercado de capitais: regime jurídico. 2. ed. Rio de Janeiro: Renovar, 2008.

FABIAN, Christoph. O dever de informar no direito civil. São Paulo: Editora Revista dos Tribunais, 2002.

FAMA, Eugene F.; LAFFER, Arthur B. Information and Capital Markets. The Journal of Business, Chicago, v. 44, p. 289-298, 1971.

FORGIONI, Paula A. Contrato de distribuição. 2. ed. São Paulo: Editora Revista dos Tribunais, 2008.

FREIRE, Maia Paula dos Reis Vaz. Eficiência Económica e Restrições Verticais. Lisboa: AAFDL, 2008.

GUARRIDES, Joaquin. Problemas atuais das sociedades anônimas. Porto Alegre: Sergio Antonio Fabris Editor, 1982.

HAYEK, Friedrich A. The Use of Knowledge in Society. The American Economic Review, Pittsburgh, v. 35, p. 519-530, 1945.

JAKOBI, Karin Bergit; RIBEIRO, Marcia Carla Pereira. A análise econômica do direito e a regulação do mercado de capitais. São Paulo: Editora Atlas, 2014.

LEÃES, Luís Gastão Paes de Barros. Mercado de capitais e “insider trading”. São Paulo: Editora Revista dos Tribunais, 1982.

LOBO, Carlos Augusto da Silveira. Constituição. In: LAMY FILHO, Alfredo; BULHÕES PEDREIRA, José Luiz (Org.). Direito das Companhias. 2. ed. Rio de Janeiro: Forense, 2017. 
MARTINS-COSTA, Judith. A Boa-Fé no Direito Privado: critérios para sua aplicação. São Paulo: Marcial Pons, 2015.

MILLER, Daniel Schiavoni. Governança corporativa e full disclosure: o direito à informação como direito subjetivo instrumental, implicitamente essencial e inderrogável do acionista. In: CANTIDIANO, Luiz Leonardo; CORREAA, Rodrigo. Governança corporativa: empresas transparentes na sociedade de capital. São Paulo: Lazulli Editora, 2004.

PEREIRA FILHO, Valdir Carlos. Entidades administradoras de mercados organizados de valores mobiliários. In: COMISSÃO DE VALORES MOBILIÁRIOS. Direito do mercado de valores mobiliários. Rio de Janeiro: Comissão de Valores Mobiliários, 2017.

PITTA, André Grünspun. O regime de informação das companhias abertas. São Paulo: Quartier Latin, 2013.

PITTA, André Grünspun; PEREIRA FILHO, Valdir Carlos. Sistema Financeiro Nacional. In: COMISSÃO DE VALORES MOBILIÁRIOS. Direito do mercado de valores mobiliários. Rio de Janeiro: Comissão de Valores Mobiliários, 2017.

SALDANHA, Nair Veras; MALUF, Luiz Rafael de Vargas. Ofertas púbicas de distribuição de valores mobiliários. In: COMISSÃO DE VALORES MOBILIÁRIOS. Direito do mercado de valores mobiliários. Rio de Janeiro: Comissão de Valores Mobiliários, 2017.

SÃO PAULO. Tribunal de Justiça do Estado de São Paulo. Quinta Câmara de Direito Privado. Apelação $\mathrm{n}^{\circ}$ 9247433-87.2005.8.26.0000. Relatora Desembargadora Christine Santini. Julgado em 23/11/2011. Publicado em 05/12/2011.

STIGLITZ, Joseph E. The revolution of information economics: the past and the future. Disponível em: https://www.nber.org/papers/w23780.pdf. Acesso em 17 de janeiro de 2020. SZTAJN, Rachel. Direito societário e informação. In: CASTRO, Rodrigo R. Monteiro; JÚNIOR, Walfrido Jorge Warde; TAVARES GUERREIRO, Carolina Dias (Org.). Direito empresarial e outros estudos de direito em homenagem ao Professor José Alexandre Tavares Guerreiro. São Paulo: Quartier Latin, 2013.

TANJI, Marcia. Mercado de capitais: formas de atuação do Estado. Tese (Doutorado em Direito) - Faculdade de Direito. Universidade de São Paulo. 2013.

YAZBEK, Otavio. Regulação do Mercado Financeiro e de Capitais. 2. ed. Rio de Janeiro: Elsevier, 2009. 